\title{
Serologic assessment of yellow fever immunity in the rural population of a yellow fever-endemic area in Central Brazil
}

\author{
Vanessa Wolff Machado ${ }^{[1]}$, Pedro Fernando da Costa Vasconcelos ${ }^{[2]}$, \\ Eliana Vieira Pinto Silva ${ }^{[2]}$ and João Barberino Santos ${ }^{[1]}$
}

[1]. Núcleo de Medicina Tropical, Universidade de Brasília, Brasília, DF. [2]. Instituto Evandro Chagas, Secretaria de Vigilância em Saúde, Ministério da Saúde, Belém, Pará.

\begin{abstract}
Introduction: The yellow fever epidemic that occurred in 1972/73 in Central Brazil surprised the majority of the population unprotected. A clinical-epidemiological survey conducted at that time in the rural area of 19 municipalities found that the highest (13.8\%) number of disease cases were present in the municipality of Luziânia, State of Goiás. Methods: Thirty-eight years later, a new seroepidemiological survey was conducted with the aim of assessing the degree of immune protection of the rural population of Luziânia, following the continuous attempts of public health services to obtain vaccination coverage in the region. A total of 383 volunteers, aged between 5 and 89 years and with predominant rural labor activities $(75.5 \%)$, were interviewed. The presence of antibodies against the yellow fever was also investigated in these individuals, by using plaque reduction neutralization test, and correlated to information regarding residency, occupation, epidemiological data and immunity against the yellow fever virus. Results: We found a high (97.6\%) frequency of protective titers $(>1: 10)$ of neutralizing antibodies against the yellow fever virus; the frequency of titers of 1:640 or higher was $23.2 \%$, indicating wide immune protection against the disease in the study population. The presence of protective immunity was correlated to increasing age. Conclusions: This study reinforces the importance of surveys to address the immune state of a population at risk for yellow fever infection and to the surveillance of actions to control the disease in endemic areas.
\end{abstract}

Keywords: Yellow fever. Vaccine protection. Luziânia. Goiás.

\section{INTRODUCTION}

Despite the ever-changing locations of occurrences of the disease in the country, for a long time the Central-West region of Brazil is part of the yellow fever's endemic and enzootic area. In Goiás, a State in the Central-West region, cases of wild-type yellow fever disease have been detected since $1935^{1}$, and in the 70's this was the State of Brazil with the highest incidence of this disease ${ }^{2}$.

During the epidemic in 1972/73, the Núcleo de Medicina Tropical da Universidade de Brasília conducted a clinicalepidemiological survey in the rural area of 19 municipalities around the Federal District. The study area corresponded to $76,558 \mathrm{~km}^{2}$ and a population of 471,133 inhabitants. At that time, we investigated 812 individuals with family members in which the disease was suspected or confirmed and identified $295(36.3 \%)$ cases of the disease, most of them $130(44.1 \%)$

Address to: Dra. Vanessa Wolff Machado. Núcleo de Medicina Tropical/UnB. Campus Universitário Darcy Ribeiro, Asa Norte, Caixa Postal 4517, 70904-970 Brasília, DF, Brasil.

Phone: 5561 3107-1844; Fax: 5561 3273-2811

e-mail: vanessawolff@yahoo.com.br

Received 17 September 2012

Accepted 26 March 2013 cases, classified as mild disease (fever without jaundice, bleeding or renal failure). Sixty-nine (23.4\%) cases were classified as moderate disease (jaundice with constitutive symptoms) and $96(32.5 \%)$ cases, as severe disease (with classical clinical presentation). Among the latter cases, the overall mortality was $94.8 \%{ }^{3}$. Only $22(7.5 \%)$ of all patients reported previous immunization against yellow fever. Most (68.1\%) patients were young adults, aged 29 years or less, and male (66.1\%). In addition, most cases were seen in December 1972. Although it is possible that some individuals may have acquired protective immunity due to previous asymptomatic or oligosymptomatic natural infection, it was noticed that a large part of the population exposed to the risk of infection had no immune defense against the arbovirosis (unpublished data).

The rural communities in Luziânia had the highest number of yellow fever cases during the epidemic in 1972/73 ${ }^{4}$. Since then, the disease has been considered of great sanitary importance to the region and these communities have been included in several vaccination campaigns. It is possible that due to these preventive actions the number of confirmed cases of yellow fever in Goiás has diminished significantly from 1990 to 2000 , to a total of 88 cases, with 45 deaths 5 .

In addition to its importance to the previous epidemic of yellow fever, the municipality of Luziânia constitutes an endemic yellow fever area, with a current rural population of 11,000, and is therefore an important target for immunization actions plans 
and epidemiological surveillance. For these reasons, we sought to investigate the degree of immune protection of this population 38 years later, by means of a serologic survey.

The aim of this survey was to investigate the impact of the intensification of immunization actions on the protection against yellow fever since the occurrence of the 1972/72 epidemics, due to the importance of periodic field surveys to acknowledge the immune state of the population exposed to the disease and to monitor control actions in endemic areas.

\section{METHODS}

\section{Study area}

Luziânia is the fifth most populated municipality in the State of Goiás and is located approximately $200 \mathrm{~km}$ from Goiânia, the state capital, and 60km from Brasília (Figure 1). It is part of the Região Integrada de Desenvolvimento (RIDE) of the Federal District. It has 174,531 inhabitants, of whom 162,807 live in the urban areas, whereas 11,724, in rural areas ${ }^{6}$. Luziânia is crossed by the rivers Corumbá, São Bartolomeu, Descoberto, Piracanjuba, and Areias, which form the basin of the Paraná River. The dominant vegetation is typical of the cerrado, with riparian forests that can be found along riverbanks along with different species of primates, mainly from Callitrichidae and Cebidae $^{7}$ families. The wild vectors are mainly of the Haemagogus and Aedes genera ${ }^{8}$.

\section{Clinical-serological survey}

The survey was conducted from August 19 to October 9, 2010 in 24 rural areas or farms affected by the epidemic in 72/73. All its inhabitants who agreed to participate in the study were included, and there were no exclusion criteria. The participants

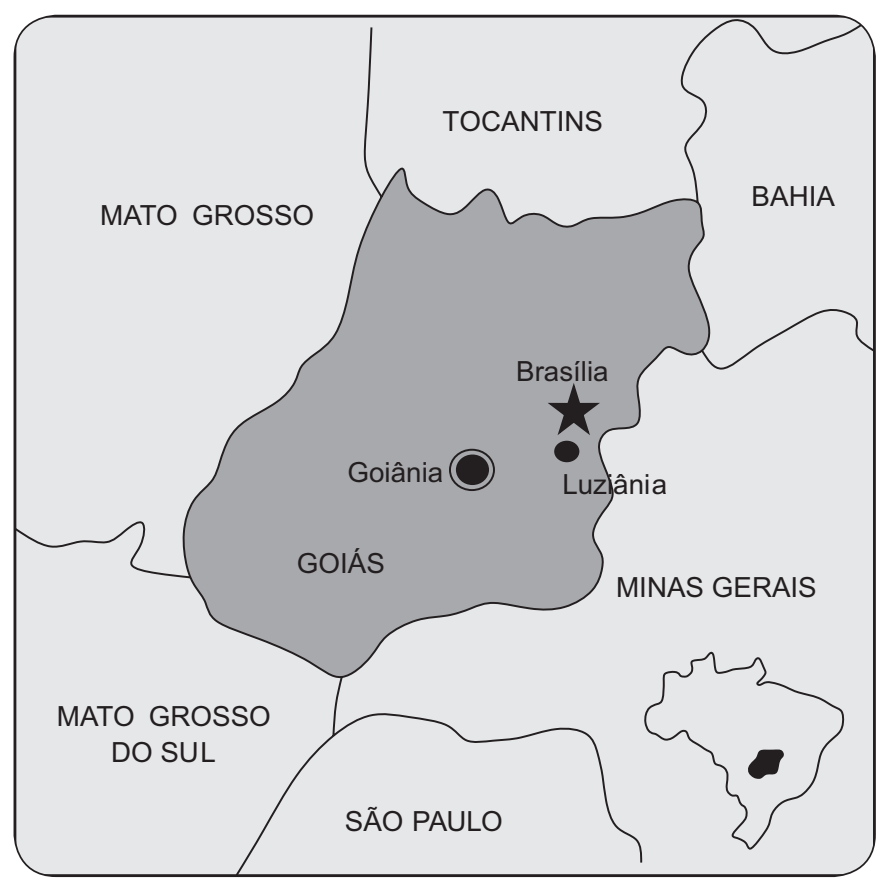

FIGURE 1 - Map of Brazil, highlighted the State of Goiás and the municipality of Luziânia. answered a previously developed questionnaire containing information about age, sex, address, occupation, lifestyle, travels, residency proximity to native vegetation and plantation, presence of primitive primates and marsupials near residency, current symptoms, general health conditions (including the occurrence of fever and jaundice with or without bleeding, from 1972 to 2010), in addition to their vaccination history. A brief physical examination foccused on the investigation of signs of anemia, jaundice, bleeding, hepato and splenomegaly. Blood samples were collected and maintained at room temperature for $2-6 \mathrm{~h}$. The serum obtained was frozen at $-20^{\circ} \mathrm{C}$ until it was sent, using containers with dry ice, to the cell culture laboratory of the Arbovirology and Hemorrhagic Fevers Department of the Evandro Chagas Institute to detect antibodies against the yellow fever virus. For this, plaque reduction neutralization test (PRNT) was adapted and used, according to the protocol described by Stefano et al. ${ }^{9}$. The samples were tested in serial dilutions (range, 1:05-1:640) and compared to an average of 20 plaque-forming units of yellow fever virus. Seropositivity was considered when the titer was above or equal to $1: 10$, whereas when the titer was below 1:10, seronegativity was considered ${ }^{10,11}$.

Vaccination was indicated in all the volunteers included in the study whose results showed low immune response against the disease.

Individuals who showed their vaccination card with the registration stamp of yellow fever vaccination and/or reported prior vaccination were considered as vaccinated. However, immunization status was considered only for those who had neutralizing antibodies titers above 1:10.

\section{Statistical analysis}

The sample size was estimated at 372 individuals, calculated as proposed by Lwanga and Lemeshow ${ }^{12}$, considering a confidence level of $95 \%$, and an error margin of $\pm 5 \%$ (or 0.05 ), in a 11,724 population (estimated rural population of Luziânia ${ }^{6}$ ). As we could not estimate the anticipated population proportion, the value of 0.5 was established.

For association tests, chi-square and Fischer tests were used, whereas for means comparisons, Student's t test and analysis of variance (ANOVA), followed by Turkey test were used. To assess the correlation between variables of normal distribution the Pearson's correlation coefficient was used. For all he tests mentioned above, the results were considered statistically significant when $\mathrm{p}<0.05$.

\section{Ethical considerations}

The research project was approved by the Ethics Committee on Human Research of the Faculty of Medicine of the University of Brasília, under the registration data CEP-FM/UnB n: $041 / 2010$.

\section{RESULTS}

\section{Clinical-epidemiological survey}

We interviewed 383 volunteers who were residents in the rural area of Luziânia. The average residency time in the region was 19.58 years (range, $0-81$ years; median, 12 years). The age of the individuals participating in the study varied between 5 and 
89 years old (average age, 39.2 years), of which 211 (55.1\%) were women and 172 (44.9\%), men.

The majority of the people included in the survey were natives, 243 (63.4\%), whereas 140 (36.6\%) were from other regions, mainly from the northeastern states $(47.1 \%)$. The main activities (75.5\%) were conducted in the rural area, being mostly farmers, housewives, health officials, caretakers, and students. The presence of woodland near residency was reported by $348(90.4 \%)$ of the subjects, and in $284(82.1 \%)$ cases the distance from woodland to residency was smaller than $500 \mathrm{~m}$. Vegetable and fruit-gardens near residency were reported by 337 $(88 \%)$ individuals, whereas the frequency of primitive primates near residency was $222(58 \%)$.

Twenty (5.2\%) residents did not recall whether they had underwent prior yellow fever vaccination, whereas 15 (3.9\%) stated that they had not received any vaccination. Out of $348(90.9 \%)$ individuals who received prior vaccination, $70(20.1 \%)$ could not remember the number of doses that they received. Among the 278 (79.9\%) individuals who informed the number of doses that they received, an average of 2.7 individuals received doses varying between 1 and 10 . Further, $94.6 \%$ of these individuals received up to 5 doses of the vaccine (Figure 2). Additionally, 19 (5.5\%) claimed that they were vaccinated more than 10 years ago; 244 (70.1\%), less than 10 years ago; and 85 (24.4\%), did not recall the date of the last vaccination.

Among the interviewees, $3(0.8 \%)$ individuals had prior occurrence of yellow fever: one manifested the disease 2 years before the study, whereas the others, 38 and about 50 years before, respectively. They were all residing in the State of Goiás while presenting the disease. All 3 stated that, once recovered, they were vaccinated against yellow fever.

During the study, none of the participants presented alterations in the clinical examinations.

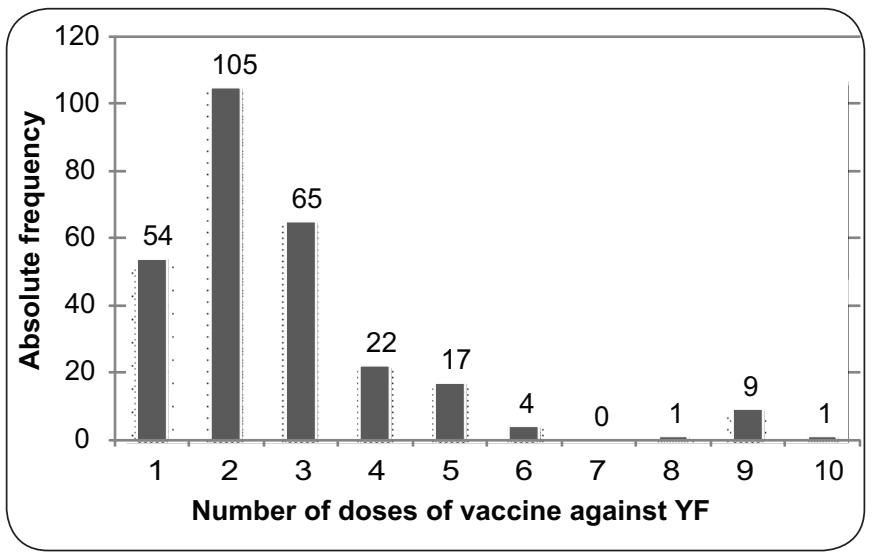

FIGURE 2 - Distribution of the individuals interviewed and vaccinated against yellow fever in the rural area of the municipality of Luziânia, in 2010, according to the number of doses of vaccine already received. YF: yellow fever.

\section{Serological survey}

The 383 participants in the study underwent serological analysis by using the PRNT. A total of $374(97.6 \%)$ volunteers presented positive values (titers above 1:10); $7(1.8 \%$ ), negative (below 1:10); and $2(0.5 \%)$ borderline titer values (1:10). Among the individuals with titer values above $1: 10$, the average titration was $1: 329$, after considered the majority of those examined $(89[23.2 \%])$ had a titer $\geq 1: 640$. Thus, it was not possible to establish a correlation between the post-vaccination time and the yellow fever antibody titer.

In the assessment of variables referring to personal data with the immunity against yellow fever, a correlation was found $(p=0.016)$ only between the ages of the participants in the survey (Table 1 and Figure 3).

Nine $(2.3 \%)$ people interviewed showed no immune protection, including 5 women and 4 men; of these, 6 were aged under 12-years-old whereas 3 were aged between 41 and 58 years.

TABLE 1 - Analysis of the association of demographic, epidemiological, and clinical variables, with yellow fever immune status ${ }^{\mathrm{a}}$

\begin{tabular}{|c|c|c|}
\hline & OR $(95 \% \mathrm{CI})$ & $\mathrm{p}$ \\
\hline Gender & $1.0194(0.2695-3.8562)$ & 0.9774 \\
\hline Age & $1.054(1.009-1.099)$ & 0.016 \\
\hline Time of residency & $1.0358(0.9836-1.0907)$ & 0.1828 \\
\hline Occupation (inside rural area/outside rural area) ${ }^{b, c}$ & -- & -- \\
\hline Primates in peridomestic habitats & $1.38(0.29-6.68)$ & 0.46 \\
\hline Type of vegetation (cerrado/riparian forest) in peridomestic habitats & $0.44(0.02-3.59)$ & 0.38 \\
\hline Plantation in peridomestic habitats & $0.9726(0.1186-7.9773)$ & 0.9794 \\
\hline Vaccination against $\mathrm{YF}$ & $0.3294(0.0385-2.8180)$ & 0.3106 \\
\hline Prior $\mathrm{YF}^{\mathrm{b}, \mathrm{d}}$ & -- & -- \\
\hline
\end{tabular}

YF: yellow fever; OR: odds ratio; CI: confidence interval; ${ }^{a}$ titers $>10$, positive or immune; and $\leq 10$, negative or non-immune; $b_{\text {impaired analysis due to the absence of a }}$

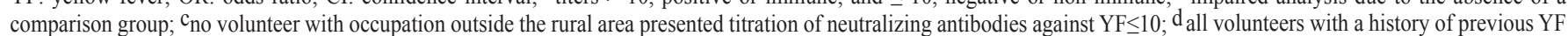
presented titration of neutralizing antibodies against yellow fever $>10 ;{ }^{e}$ only one volunteer with prior jaundice history showed titration of neutralizing antibodies against $Y F>10$. 


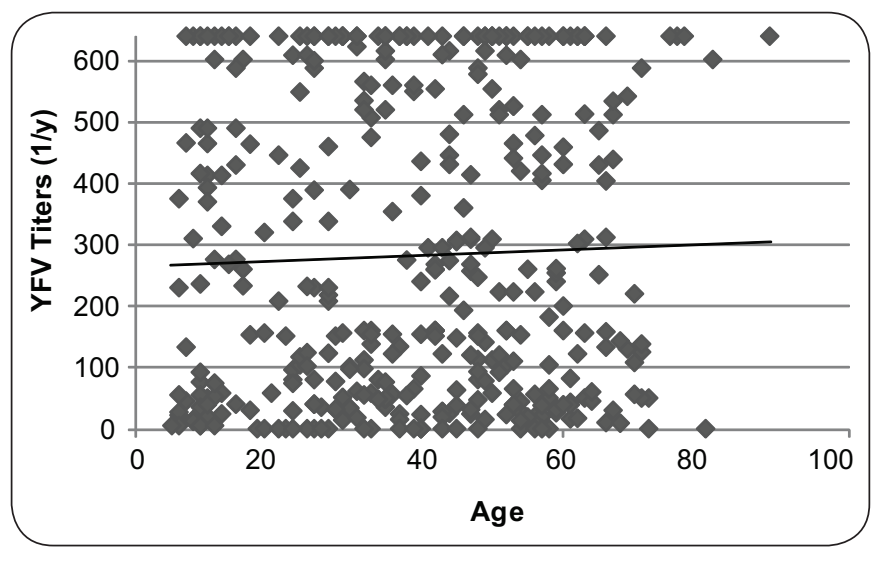

FIGURE 3 - Distribution of neutralizing antibodies titers in 383 individuals examined in rural Luziânia in 2010, according to age. YFV: yellow fever vaccines.

Among the adults, one stated that he was a rural worker and the other 2 did household chores. The time of residence in their current location varied between a few months to up to 41 years. Four individuals denied the presence of non-human primates around their homes, whereas 5 confirmed it. With the exception of one individual, 8 among those interviewed were vaccinated against yellow fever (1, 7 years ago; and 7, 2 years ago). Among the 6 individuals who claimed to have received prior vaccination, one individual received 3 doses; two, 2 doses; and three, one dose.

\section{DISCUSSION}

Although the current annual number of cases of yellow fever in Brazil reported rarely exceed 40 notifications ${ }^{5}$, the last revision of the occurrence area of the disease in Brazil has indicated the expansion of yellow fever, between 2007 and 2009, to the reaching unvaccinated population in the States São Paulo, Paraná and Rio Grande do Sul. However the State of Goiás is still responsible for a significant number of yellow fever cases. In the 70 s, Goiás was the Federal State that registered a high number of yellow fever cases ${ }^{2}$ in the country, as its rural population was shown to be the most susceptible to this pathology ${ }^{8}$.

During the epidemic in the summer of 1972/73, which occurred in Central Brazil, the Núcleo de Medicina Tropical da Universidade de Brasília (NMT-UnB) promoted a clinicalepidemiological survey in the rural area of 19 affected municipalities, 18 belonging to the State of Goiás. Thirty-eight years later, the rural communities in the municipality of Luziânia were revisited. This municipality is located in the middle of the endemic area in which the highest number of disease cases was registered during the epidemic. A serological re-evaluation was conducted with the aim of verifying the real degree of current immune protection of the population that has been continuously exposed to the risk of infection.

The result of the survey conducted in $1972 / 73$ by the NMT/UnB showed a higher frequency of disease cases (295) and deaths (91) than those officially registered, namely, 71 and 44 cases, respectively ${ }^{8}$. In fact, many cases occurring in wild regions are left unreported, suggesting a yellow fever iceberg hypothesis ${ }^{13}$. Yellow fever has a wide spectrum of possible clinical presentations, from asymptomatic to severe cases, and therefore its clinical diagnosis may be challenging in situations other that epidemics, particularly in the absence of bleeding and renal dysfunction ${ }^{14}$. Even during outbreaks, it may be misdiagnosed as other diseases that present with jaundice and bleeding, such as leptospirosis, which may be occur concomitantly in regions affected by yellow fever. In reality, the frequency of disease cases must be even higher than what was revealed by the study promoted by the NMT/UnB, which aimed at families in which at least one confirmed episode of yellow fever was detected. A correlation between the absence of vaccination prior to disease and severe forms of the pathology was confirmed. The result of the serological tests with $56.4 \%$ negative titers in 55 serum samples obtained from unvaccinated individuals show that a large part of the population was without immune protection against arbovirosis, thus, being susceptible to infection (unpublished data).

Since the implementation of the yellow fever vaccine in 1998, as part of the Expanded Program of Immunization ${ }^{15}$, the vaccination coverage in the State of Goiás has achieved much higher rates than that of previous immunizations. In 2010, the official vaccination coverage (based on applied doses) in the municipality of Luziânia reached $100.8 \%{ }^{16}$. Considering this improvement, it is safe to assume a similar increase in immunological protection of the studied population in 2010 than that in 1972/73.

In the survey conducted in 2010, the majority of the population interviewed were young individuals, aged between 20 and 59 years old, working at or near the place of residence and living mainly in a rural setting. Most of the people interviewed were residing in that region for more than 10 years, showing stability in the place of residence, in addition to the proximity to woodlands and to primitive primates, which are important factors in the sylvatic cycle of yellow fever transmission ${ }^{17}$. Thus, no significant change from the time of the epidemic in 1972/73 was observed in age, migratory as well as occupational characteristics of the population living in the study area.

Although the vaccination coverage foreseen by the National Program of Immunization is $100 \%$ for municipalities located in the risk zone, $3.9 \%$ of the individuals interviewed reported no prior vaccination. Although $90.9 \%$ received prior vaccination against yellow fever, we can infer a higher frequency of vaccinated individuals than that reported. This is possible by assuming a recall bias, that those unaware of receiving prior vaccination were vaccinated either at some point in their lives but did not remember or became infected and developed mild or oligosymptomatic forms of the disease. Thus, although the information suggests that the vaccination coverage was below that recommended by the Ministry of Health, it might still be considered a high vaccination coverage ${ }^{18}$. However, the serological survey showed that $97.7 \%$ of the individuals presented protective levels of neutralizing antibodies. This enabled us to conclude that in that region, the vaccination coverage against yellow fever was effective, because evident progress was observed than that after the epidemic of 1972/73, which affected most of the unprotected population. 
Eight individuals reported previous vaccination, in some of them confirmed by information in the immunisation card, but did not show protective titers of antibodies. Some hypothesis were drawn to explainthis finding: a) the possibility of confusion with vaccination against other disease, which could have been offered to the inhabitants of the studied area in the same period as yellow fever vaccination; $b$ ) the interference of other vaccines, administered simultaneously, in the immune response; c) inadequate storing conditions of the vaccine, preceding its administration; d) impairment of the immune response in some individuals. Unfortunately, our results preclude the exact definition of the mechanisms underlying the absence of protective antibodies in individuals who reported previous vaccination.

The data that $94.6 \%$ of the individuals received up to 5 doses of the vaccine reflects the increase in vaccination coverage over the past years, since the inclusion of the vaccine in immunization programs for children and adults by the World Health Organization (WHO) and the Pan American Health Organization and its implementation in the Expanded Program on Immunization in $1998^{16}$.

To evaluate the protective immune response against yellow fever, PRNT was used as the gold standard, since it showed higher sensitivity and specificity to assess protective immunity than other serological tests ${ }^{19,20}$. Plaque reduction neutralization test measures antibodies against neutralizing epitopes and determines antibody functionality, a parameter correlated with high specificity for protective immunity ${ }^{21}$. Neutralizing antibodies against yellow fever virus are different from those against other flaviviruses ${ }^{21}$, a feature that renders this test highly specific. Although it cannot differentiate antibodies induced by natural infection from those induced by active immunization, this does not invalidate the current study, which was designed to investigate the immune state of the population against the disease. There is no consensus on the titration conferring immunity. However, the values used as positive, i.e., values more than 10 are well accepted in the literature ${ }^{10,11,19,21,22}$.

While assessing a possible association with variables referring to personal data, only a correlation between the older individuals interviewed and high titer of the neutralizing antibodies was established. Probably, this was due to multiple exposures and/or vaccinations. No indicative data were confirmed, because no consensus was found in the literature regarding the higher titers shown by Caucasians than by Blacks and Hispanics, as well as by men than by women ${ }^{20,22-24}$. In a Brazilian study, a lower seroconversion rate was observed on antibody levels after vaccination against yellow fever in 12-month-old children who simultaneously received the triple viral vaccine than in those who received the 30-day interval vaccination. In the same study, an increased probability of presenting primary failure was shown in children with median age of 9 months, who developed no humoral response to the first dose of vaccination than in children with a median age of 12 months. This effect was observed despite most of the children presenting humoral response after the second vaccine dose, although they showed no response to primary vaccination ${ }^{25}$. Presumably, the majority of the children, who were residents in the rural areas of Luziânia, were simultaneously immunized with other vaccines because of their obvious difficulty in accessing health services. Most of the rural community was vaccinated during vaccination campaigns. This might be an explanation for the correlation established between the children interviewed and their low titers of neutralizing antibodies.

Among the 15 individuals who had never been vaccinated against yellow fever before, only one did not show neutralizing antibodies. Presumably, those with immunization had a recall bias or had prior vaccination in some point in their lives, particularly during childhood, or may have developed protective antibodies due to an asymptomatic or oligosymptomatic form of the disease. It is unlikely that individuals showing neutralizing antibodies against yellow fever virus, although denying prior vaccination, developed these antibodies because of crossimmunity with other arboviruses. Further, to supporting this observation, the PRNT detects antibodies against neutralizing epitopes that are specific to the yellow fever virus.

Despite the official numbers for vaccination coverage, no immunological protection was observed in $9(2.3 \%)$ people interviewed, among whom 3 were adults. With the exception of one individual who denied prior vaccination, 8 stated that they received vaccination against yellow fever at some point in their lives. As a seroconversion rate of above $90 \%$ is expected in adults immunized with a 17DD vaccine $\operatorname{strain}^{21,26}$. The vulnerability in the serologic response of this group, which includes 3 adults, might be explained by a failure to develop neutralizing antibodies because of simultaneous vaccination with other attenuated virus vaccines, which may have inhibited the replication of the other vaccinal virus due to the production of interferon ${ }^{27-29}$. Other factors that may influence the immune response to the vaccine against yellow fever include previous immunity against related antigens, crossed protection against flavivirus, immunosuppression due to diseases or drugs, severe undernutrition and pregnacy ${ }^{30}$, in addition to difficulties in the handling/preservation of the vaccine during administration. It has been shown that children aged 12 months or less have reduced rates of serologic conversion and after vaccination against yellow fever when compared to children aged 2 years or more or to adults ${ }^{31}$.

Although the serologic test used in this study cannot distinguish between antibodies induced by natural infection from those induced by vaccination, the fact that $97.6 \%$ of the individuals tested showed protective antibody titers against yellow fever, in addition to the reducing incidence rates of the disease in the last decade, suggest that control actions including a wide vaccination programme have reached good results in the studied area.

It would be of additional interest to verify the immune response after (re)vaccination of the 9 volunteers who did not show immune protection, so that the absence or low immune response after vaccination could be confirmed, particularly in individuals who stated receiving prior vaccination.

This study reinforces the importance of surveys to address the immune state of a population at risk for yellow fever infection and to the surveillance of actions to control the disease in endemic areas. 


\section{CONFLICT OF INTEREST}

The authors declare that there is no conflict of interest.

\section{REFERENCES}

1. Franco O. História da febre amarela no Brasil. Departamento Nacional de Endemias Rurais. Rio de Janeiro: Ministério da Saúde; 1969.

2. Vasconcelos PFC. Febre amarela: reflexões sobre a doença, as perspectivas para o Século XXI e o risco da reurbanização. Rev Bras Epidemiol 2002; 5: 244-258.

3. Santos JB. Inquérito clínico epidemiológico no surto de febre amarela de 1973, em 19 Municípios no Brasil Central. Anais do XIII Congresso da Sociedade Brasileira de Medicina Tropical e II Congresso da Sociedade Brasileira de Parasitologia. Brasília, Distrito Federal; 1977. 300p.

4. Pinhero FP, Travassos-da-Rosa APA, Moraes MA, Almeida Neto JC, Camargo S, Filgueiras FP. An epidemic of yellow fever in Central Brazil, 1972-1973. I. Epidemiological studies. Am J Trop Med Hyg 1978; 27:125-32.

5. Ministério da Saúde. Casos de febre amarela, Brasil, Grandes Regiões e Unidades Federadas. 1990-2010. Serviço de Vigilância Sanitária. Brasília: Ministério da Saúde; 2010. [Cited 2012 January 12]. Available from: http://portal.saude.gov. br/portal/arquivos/pdf/tabela_1_fa_2010.pdf.

6. Instituto Brasileiro de Geografia e Estatística (IBGE) [Internet]. Censo Demográfico 2010. Brasília: IBGE; 2010. [Cited 2012 January 12]. Available from: www.ibge.gov.br/

7. Deane LM, Ferreira Neto JA. Malária de macacos no Estado de Goiás, Brasil: encontro de guaribas, Alouatta caraya, infectados com Plasmodium brasilianum. Rev Inst Med Trop São Paulo 1973; 15:107-111.

8. Ministério da Saúde. Manual de vigilância de epizootias em primatas nãohumanos. Brasília, Distrito Federal: Secretaria de Vigilância em Saúde; 2005.

9. Stefano I, Sato HK, Pannuti CS, Omoto TM, Mann G, Freire MS, et al. Recent immunization against measles does not interfere with the sero-response to yellow fever vaccine. Vaccine 1999; 17:1042-1046.

10. Lang J, Zuckerman J, Clarke P, Barret P, Kirkpatrick C, Blondeau C. Comparison of the immunogenicity and safety of two 17D yellow fever vaccines. Am J Trop Med Hyg 1999; 60:1045-1050.

11. Monath TP, Fowler E, Johnson CT, Balser J, Morin MJ, Sisti M, et al. An inactivated cell-culture vaccine against yellow fever. N Engl J Med $2011 ; 364: 1326-1333$.

12. Lwanga SK, Lemeshow S. Sample size determination in health studies A practical manual. $1^{\text {st }}$. ed. Geneva: World Health Organization; 1991.

13. Vasconcelos PFC. Febre amarela. Rev Soc Bras Med Trop 2003; 36:275-293.

14. Almeida Netto JC. Aspectos clínicos e fisiopatológicos da febre amarela. Rev Pat Trop 1991; 20:43-50.

15. Ministério da Saúde. Situação da febre amarela no Brasil, Fundação Nacional de Saúde. Bol Eletr Epid 2001; 2:1-3. [Cited 2012 January 12]. Available from: http://portal.saude.gov.br/portal/arquivos/pdf/ano01 n02 fa sit_epid br.pdf.

16. Ministério da Saúde. Dados do Programa Nacional de Imunizações (PNI) 2010. [Cited 2012 September 3]. Available from: http://tabnet.datsus.gov.br/cgi/tabcgi. exe?pni/CNV/CPNIGO.def/.
17. Pinheiro FP, Travassos-da-Rosa APA, Moraes MAP. An epidemic of yellow fever in Central Brazil, 1972-1973. II. Ecological studies. Am J Trop Med Hyg 1981; 30:204-211.

18. Moreno ES, Marques D, Figueira G, Fred J, Almeida RD, Albernaz RK, et al. Inquérito de cobertura vacinal e evento adverso à vacina de febre amarela no Município de Buri São Paulo, Brasil, 2009. BEPA 2009; 6. [Cited 2012 January 12]. Available from: http://www.cve.saude.sp.gov.br/agencia/bepa71 inquerito. htm.

19. Niedrig M, Lademann M, Emmerich P, Lafrenz M. Assessment of IgG antibodies against yellow fever virus after vaccination with 17D by different assays: neutralization test, haemagglutination inhibition test, immunofluorescence assay and ELISA. Trop Med Int Health 1999; 4:867-871.

20. Niedrig M, Kursteiner O, Herzog C, Sonnenberg K. Evaluation of an indirect immunofluorescence assay for detection of immunoglobulin $\mathrm{M}$ (IgM) and $\operatorname{IgG}$ antibodies against yellow fever virus. Clin Vaccine Immunol 2008; 15:177-181.

21. Melo AB, Silva MPC, Magalhães MCF, Gil LHVG, Carvalho EMF, Braga-Neto UM, et al. Description of a prospective 17DD yellow fever vaccine cohort in Recife, Brazil. Am J Trop Med Hyg 2011; 85:739-747.

22. Kay A, Chen LH, Sisti M, Monath TP. Short report: yellow fever vaccine seroconversion in travelers. Am J Trop Med Hyg 2011; 85:748-749.

23. Monath TP, Nichols R, Archambault WT, Moore L, Marchesani R, Tian J, et al. Comparative safety and immunogenicity of two yellow fever 17D vaccines (ARILVAX and YF-VAX) in a phase III multicenter, double-blind clinical trial. Am J Trop Med Hyg 2002; 66:533-541.

24. Hepburn MJ, Kortepeter MG, Pittman PR, Boudreau EF, Mangiafico JA, Buck PA, et al. Neutralizing antibody response to booster vaccination with the $17 d$ yellow fever vaccine. Vaccine 2006; 24:2843-2849.

25. Collaborative Group for Studies With Yellow Fever Vaccine. Randomized, double-blind, multicenter study of the immunogenicity and reactogenicity of 17DD and WHO 17D-213/77 yellow fever vaccines in children: implications for the Brazilian National Immunization Program. Vaccine 2007; 25:3118-3123.

26. Camacho LAB, Freire MS, Leal MLF, Aguiar SG, Nascimento JP, Iguchi T, et al. Collaborative Group for the Study of Yellow Fever Vaccines. Immunogenicity of WHO-17D and Brazilian 17DD yellow fever vaccines: a randomized trial. Rev Saude Publica 2004; 38:671-678.

27. Meyer Jr HM, Hostetler Jr DD, Bernhein BC, Rogers NG, Lambin P, Chassary A, et al. Response of Volta children to jet inoculation of combined live measles, smallpox and yellow fever vaccines. Bull World Health Organ 1964; 30: 783-794.

28. Wheelock EF, Sibley WA. Circulating virus, interferon and antibody after vaccination with the 17-D strain of yellow fever virus. N Engl J Med 1965; 273:194-198

29. Petralli JK, Merigan TC, Wilbur JR. Circulation interferon after measles vaccination. N Engl J Med 1965; 273:198-201.

30. Belmusto-Worn VE, Sanchez JL, McCarthy K, Nichols R, Bautista CT, Magil AJ, et al. Randhomized double-blind phase III, pivotal field trial of the comparative immunogenicity, safety and tolerability of two yellow fever $17 \mathrm{D}$ vaccines (Arilvax, and YF-Vax) in healthy infants and children in Peru. Am J Trop Med Hyg 2005; 72:189-197.

31. Grupo Colaborativo do Programa Nacional de Imunizações para o Estudo da Soroconversão pela Vacina contra Febre Amarela. Immunogenicity of 17DD and WHO 17D-213/77 yellow fever vaccines in children younger than 2 year-old: a randomized, double-blind study. In: World Society for Pediatric Infectious Diseases. Thailand (Bangkok). 2007. 